\title{
Chemical, diversity and biotechnological potential of endophytic fungi isolated from Brazilian Cerrado plants
}

\author{
Sara Bruna Souza Dantas ${ }^{I}$, Flavia Alessandra Mota Alves ${ }^{I}$ \& Vanessa Mara Chapla ${ }^{1 * 10}$ \\ ${ }^{1}$ Universidade Federal do Tocantins, Programa de Pós-graduação em Química, 77402-970, Gurupi, TO, Brasil. \\ *Corresponding author: Vanessa Mara Chapla, e-mail:vmchapla@uft.edu.br
}

DANTAS, S.B.S., ALVES, F.A.M., CHAPLA, V.M. Chemical, diversity and biotechnological potential of endophytic fungi isolated from Brazilian Cerrado plants. Biota Neotropica 21(2): e20201069.

https://doi.org/10.1590/1676-0611-BN-2020-1069

\begin{abstract}
This is a systematic review of scientific articles reporting the biodiversity of endophytic fungi isolated from endemic Cerrado plants in Brazil and exposes the potential applications of these microorganisms in the production of known and new metabolites. The "Portal de Periódicos" (CAPES), Science Direct, PubMed, Scielo, and Biblioteca Virtual em Saúde (BVS) databases were used. A total of 418 articles were found using the following sets of keywords: Endophytic, fungi, and Cerrado; endophytic, fungi, rupestrian, and grass lands; endophytic, fungi, Brazilian, and savanna; among these, 14 articles were selected. The articles were grouped into studies on the biodiversity of Cerrado endophytic fungi, chemical studies, and other subjects. All the articles were found to be related to the diversity present in the Cerrado of the southeastern and midwestern regions, they show high fungal biodiversity with Diaporthe genus predominant in almost all plants studied. In all the studies on the chemical diversity of endophytic fungi, new compounds or new natural products were found associated with a range of bioactivity, especially antifungal. It shows the great potential of endophytes in the production of new and bioactive secondary metabolites, as well as the unexplored chemical diversity of endophytes isolated from endemic plant species. The review shows that rare studies performed in regions where the Cerrado biome are predominant, including the central, north, and northeast regions, representing an important niche that is still unexplored.
\end{abstract}

Keywords: Endophytic fungi; Cerrado; Biotechnology; Natural products; Biodiversity.

\section{Química, diversidade e potencial biotecnológico de fungos endofíticos isolados de plantas do Cerrado Brasileiro}

\begin{abstract}
Resumo: Esta é uma revisão sistemática de artigos científicos que relatam a biodiversidade de fungos endofíticos isolados de plantas endêmicas do Cerrado no Brasil, e expõe as possíveis aplicações desses microrganismos na produção de metabólitos novos e conhecidos. Foram utilizadas as bases de dados "Portal de Periódicos" (CAPES), Science Direct, PubMed, Scielo e Biblioteca Virtual em Saúde (BVS). Foram encontrados 418 artigos, usando os seguintes conjuntos de palavras-chave: Endophytic, fungi, and Cerrado; endophytic, fungi, rupestrian, and grasslands; endophytic, fungi, Brazilian, and savanna. Destes, 14 artigos foram selecionados. Os artigos foram agrupados em estudos sobre a biodiversidade de fungos endofíticos do Cerrado, estudos químicos e outros estudos. Todos os artigos foram relacionados à diversidade presente no Cerrado das regiões sudeste e centro-oeste, estes apresentam alta biodiversidade fúngica, com o gênero Diaporthe predominando em quase todas as plantas estudadas. Em todos os estudos sobre a diversidade química de fungos endofíticos, novos compostos ou novos produtos naturais foram identificados, associados a uma série de bioatividades, especialmente antifúngica. Isso mostra o grande potencial dos endófitos na produção de metabólitos secundários novos e bioativos, bem como a diversidade química inexplorada de endófitos isolados de espécies de plantas endêmicas. Esta revisão mostra que raros estudos foram realizados em regiões onde o bioma Cerrado é predominante, incluindo as regiões central, norte e nordeste, que representam um nicho importante ainda inexplorado.
\end{abstract}

Palavras-chave: Fungos endofiticos; Cerrado; Biotecnologia; Produtos naturais; Biodiversidade. 


\section{Introduction}

Endophytic fungi are a highly diverse group of microorganisms that asymptomatically inhabit the interior of healthy plant tissues (Arnold 2007, Huang et al. 2001). Research on endophytic microorganisms is aimed at understanding the ecology and evolution of these microorganisms, their impact on plant communities, and the natural bioactive compounds that these microorganisms produce (Aly et al. 2011). Considering some endophytes have specific hosts, the wide diversity of biomes and endemic plants found in Brazil represent a potential source of unknown endophytic species (Savi et al. 2019).

The Cerrado, also known as the Brazilian savanna, is the second largest biome in Brazil and is located mainly in the central part of the country (Figure 1). In this biome, there is a rich chemical and biological diversity associated with plant species and microorganisms that can withstand extreme environments, such as high temperature and poor water availability over a long period of the year (Rodrigues et al. 2016). The Cerrado has $\sim 7,000$ plant species and it is estimated that $\sim 4,400$ of these are endemic, potentially edible, medicinal, wood suppliers, and other industrial raw materials (ICMBio 2018, Silva et al. 2015).

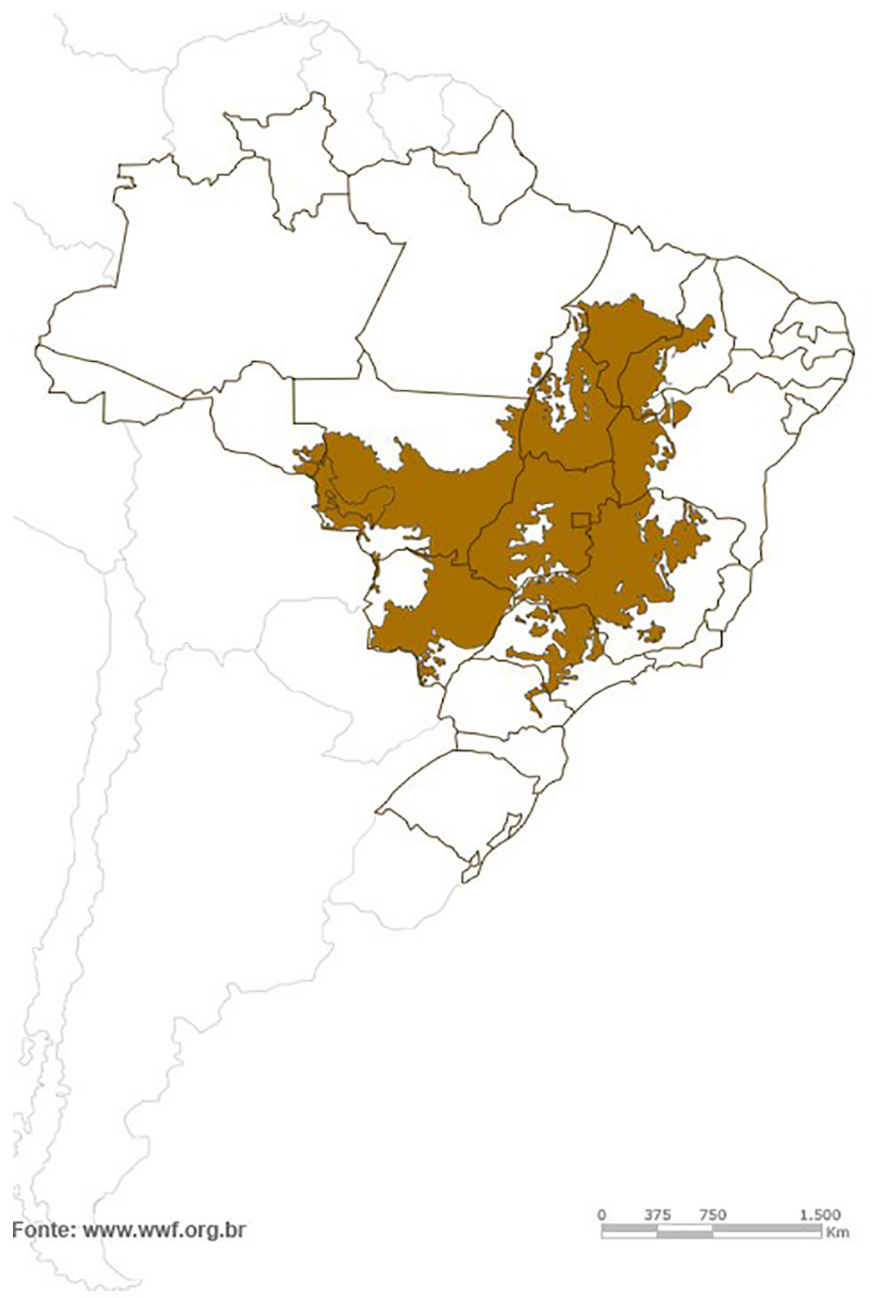

Figure 1. Location of the Cerrado biome in Brazil (Source: WWF, 2019)

According to Silva et al. (2015) the Cerrado is one of the most threatened biomes owing to increased agricultural activity. It is among the regions of the world with the richest and most endangered biodiversity (ICMBio 2018). Therefore, studies have been focused on bioprospecting its plant species and associated microbiota to identify and ensure the existence of this rich biodiversity.

Therefore, this review brings together publications reporting the endophytic fungal diversity residing in the endemic plants of the Cerrado, as well as the diversity of the metabolites they produced. In addition, we have included important chemical studies carried out to understand the relationship between the incidence, biodiversity, and production of the metabolites of endophytic fungi isolated from this biome.

\section{Material and Methods}

To identify the articles for this review, firstly we searched the "Portal de Periódicos" in CAPES, a Brazilian federal agency, which gives access to several databases. We also individually searched the Biblioteca Virtual em Saúde (BVS), PubMed, Science Direct, and Scielo databases between August and September 2019. The search strategy consisted of using the following keywords: Endophytic, fungi, and Cerrado; endophytic, fungi, rupestrian, and grasslands; endophytic, fungi, Brazilian, and savanna. The choice of these keywords was made based on the other names used in regard to the Cerrado biome, which is often reported as the rupestrian fields or Brazilian savanna.

After searching the databases and applying the inclusion and exclusion criteria, studies identified as duplicates (that is, containing the same title, author and year of publication) were identified and excluded. The inclusion criteria were: Original and research articles reporting the biodiversity of Cerrado endophytic fungi covering chemical, biological and other studies, in all languages. The excluded articles were grouped into: repeated, irrelevant (consider not connected with the subject studied), review, and other publication formats (book chapter, public notice, short communications, reports, perspectives, and letters). Manual searches were also performed using bibliographic references of the articles included in the review. There was no loss of studies by the exclusion criteria chosen.

The data obtained from the selected articles and their subsequent analysis resulted in two tables containing information obtained from these studies.

\section{Results}

After removing the repeated articles obtained using the various search databases, the exclusion criteria were applied as shown in Figure 2. Of the remaining 418 articles, 14 original research articles on endophytic fungi isolated from the Cerrado were evaluated.

The data obtained from the selected articles and their subsequent analysis resulted in two tables: Table 1 contains information regarding the authors, year of publication, study site, host plant, and isolated endophytic fungi. Table 2 lists the articles grouped according to the type of study performed, including articles on the diversity and biological activities of Cerrado endophytic fungi, chemical studies on Cerrado endophytic fungi, and other subjects.

\section{Discussion}

\section{Diversity of the endophytic fungi isolated from the Cerrado}

Endophytic fungi inhabit the interior of plant species without causing any immediate negative effects to their hosts (Chapla et al. 2014). In 


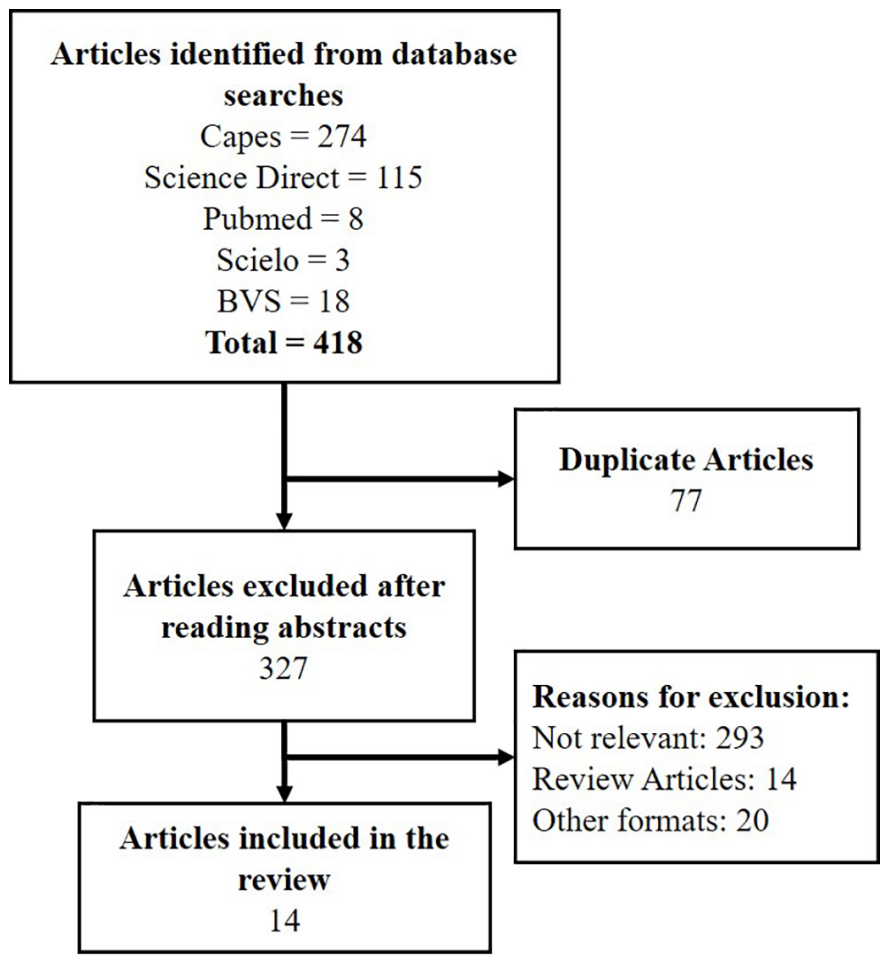

Figure 2. Identification and article selection flowchart

general, endophytic microorganisms enter the interior of plants through natural openings and wounds. Greater access for endophytes is obtained through the plant roots, but can be caused by natural openings, such as stomata and hydatodes, openings caused by insects and pathogenic fungal structures (Azevedo 1998). These microorganisms have stimulated the interest of the scientific community owing to their invaluable biological and chemical diversity, and have been considered as potential sources for the production of metabolites of economic interest, including those related to the host plants (Oliveira et al. 2013, Gonçalves et al. 2017).

Although rich and valuable, endophytic biodiversity is still poorly understood and exploited. According to Esposito \& Azevedo (2010) majority of this biodiversity is found in tropical regions, such as the Cerrado, which have immense chemical and biological diversity associated with their microorganisms and endemic plant species. In this sense, studies have been directed toward bioprospecting the endophytic communities associated with the plant species found in this biome.

Noriler et al. (2018) evaluated the biodiversity of endophytic fungal communities associated with the medicinal plants, Stryphnodendron adstringens (from Cerrado) and Vochysia divergens (from Pantanal). Of the 1,146 endophytic fungi, 339 were isolated from $S$. adstrigens. Molecular analyzes revealed Ascomycota as the predominant phylum among the isolates and Diaporthe was identified as the main genus. The extracts of Diaporthe cf. inhibit the mycelial growth of plant pathogens, also presenting antimicrobial activity against Staphylococcus aureus and Candida albicans, and represent an alternative in the biological control of these pathogens.

Diaporthe has also been identified as the dominant genus in $S$. adstringen by Carvalho et al. (2012), along with Guignardia and Preussia. 320 endophytes were isolated, which were classified into 66 phylotypes and 25 different genera. The endophytic community presents high richness, uniformity, and diversity based on the Margalef, Simpson, and Fisher indices, respectively. Biological evaluation of the fungal isolates showed that Diaporthe phaseolorum and Xylaria sp. exhibited anticancer activity, and the Nigrospora oryzae extract showed antifungal activity against Candida albicans and Cladosporium sphaerospermum.

A similar study was conducted on the Baccharis trimera plant, where Vieira et al. (2014) analyzed the diversity and antimicrobial activity of their endophytic fungi communities. 179 endophytic fungi were isolated and identified in 25 taxons. The most abundant species were also closely related to $D$. phaseolorume, Preussia pseudo minima and Pestalotiopsis sp. Although it presents a lower abundance of fungal isolates when compared to other plants, the richness and diversity were consistent with other studies on medicinal plant endophytes. After biological evaluation of the fungal extracts, 23 showed antimicrobial activity against at least one target microorganism.

Ferreira et al. (2017) investigated the microbial diversity associated with Vellozia gigantea, an endemic, ancient, and endangered plant species that is only found in the Cerrado grasslands. Herein, the authors isolated 285 fungi associated with the leaves and roots of the plant, which were identified in 87 taxa and 27 different genera. Diaporthe was also the most abundant genus among the isolates. Xylaria, Nigrospora, Colletotrichum and Trichoderma were also reported, which are genera often associated with tropical species. Based on the same indexes used by Carvalho et al. (2012), V. gigantea also showed high diversity indices, displaying a complex and rich microbiota with rare species not yet reported as endophytes. The authors suggested that this microbial diversity may be an important biological component that contributes to the millenary age of this plant in the natural environment.

In a later study, Ferreira et al. (2017), evaluated the antibacterial and antimalarial activities of 285 endophytes isolated from $V$. gigantea. The fungal extracts were obtained via solid medium fermentation and submitted to biological analysis, chromatographic fractionation and ${ }^{~} \mathrm{H}$ NMR analysis. Among the extracts analyzed, five presented antimicrobial and antimalarial activities. The Diaporthe miriciae extracts showed antifungal, antibacterial and antimalarial activities, as well as presenting highly functionalized secondary metabolites, such as epoxycytochalasin $\mathrm{H}$, which displays potent antimalarial activity against Plasmodium falciparum. Trichoderma effusum and three Penicillium species exhibited antibacterial activity.

The endophytic diversity changes with the host plant species (Azevedo et al. 2000), age (Arnold \& Herre 2003, Arnold et al. 2003), plant tissue type (Rodrigues 1994), climatic factors (Carroll 1988, Rodrigues 1994), and geographic distribution of the host plant (Arnold \& Herre 2003). In general, a few species are dominant in the endophytic communities of a given host and there is a certain degree of endophytic-host specificity (Azevedo 1998). In addition, diversity varies with the seasons. Several studies have shown that the diversity displayed by endophytic fungi is greater during the rainy season, when the spore dispersion is higher (Faeth \& Hammon 1997, Collado et al. 1999). The variety in terms of the fungal diversity according to the host sex (male and female) has also been studied (Fernandes et al. 2018) and can be attributed to the chemical differences between the two genera, as reported by Ferracini (1995) and Verdi et al. (2005).

\section{Chemical studies on endophytic fungi isolated from the Cerrado}

Endophyte-plant interactions are not yet clearly understood, however, are believed to be mutualistic, neutral or antagonistic (Souza 
Table 1. Endophytic fungi isolated from Cerrado biome

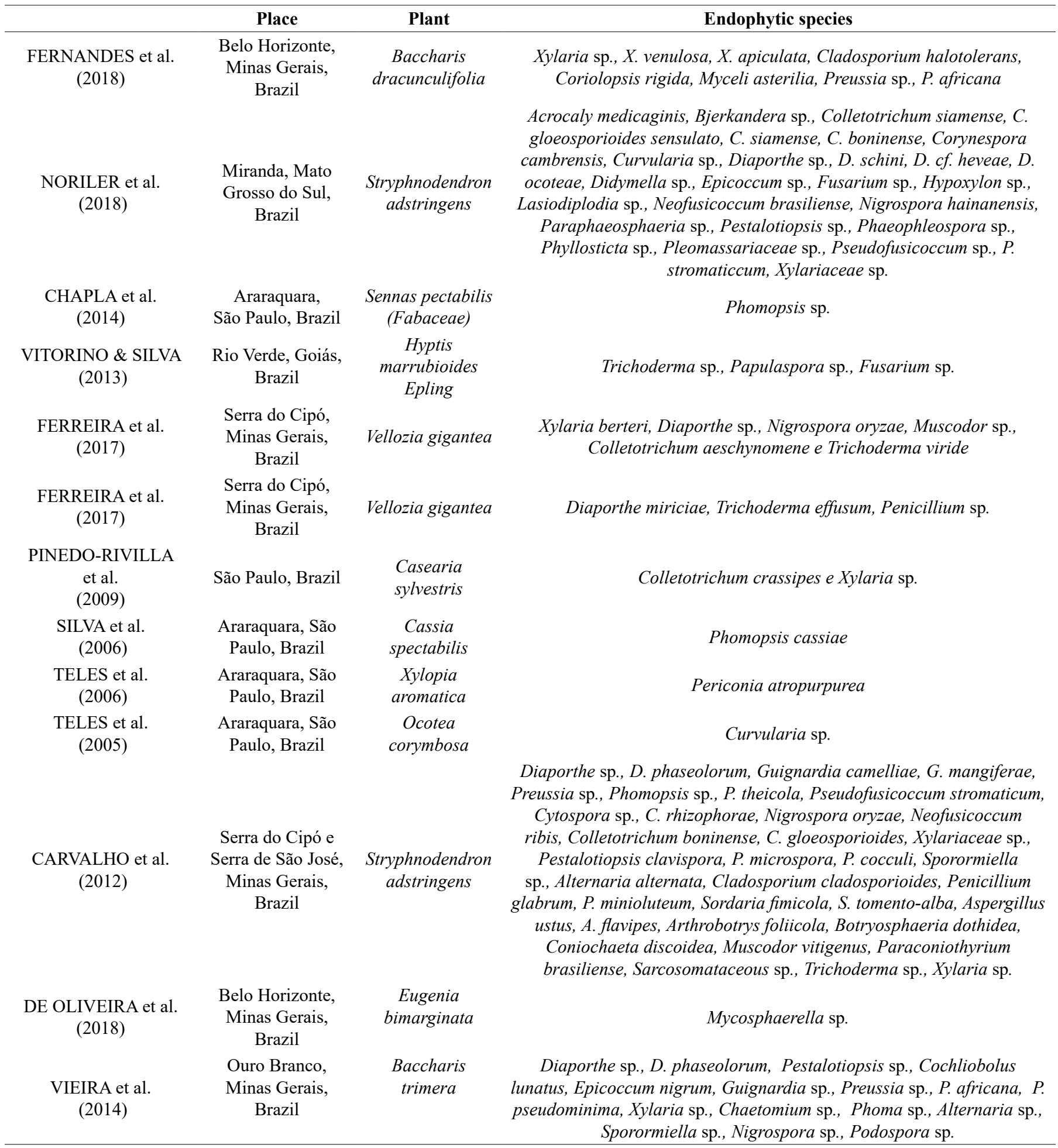

et al. 2004). In mutualistic interactions, fungi can perform functions relevant to plant health, producing substances that can protect plants against pests and pathogens, increase their tolerance to abiotic stress, and produce chemical compounds, such as hormones and antibiotics (Azevedo 1998, Souza et al. 2004).

Owing to their interaction with the host plant, many endophytes are also capable of producing the same substance synthesized by their host or bioactive analogs, which display various activities of interest, such as antibacterial, antifungal, anticancer, and immunosuppressive properties (Lacava et al. 2004, Gonçalves et al. 2017). Thus, chemical studies have been performed using endophytes mainly associated with medicinal plants in an attempt to increase the number of new biotechnological discoveries. 
Table 2. Research developed on endophytic fungi obtained from the Cerrado

\begin{tabular}{|c|c|c|}
\hline & Reference & Subjects \\
\hline \multirow{4}{*}{$\begin{array}{c}\text { Diversity and } \\
\text { biological activity }\end{array}$} & VIEIRA et al. (2014) & Diversity and antimicrobial activity. \\
\hline & CARVALHO et al. (2012) & Diversity, antimicrobial and anticancer activities. \\
\hline & FERREIRA et al. (2017) & Taxonomy and diversity. \\
\hline & FERREIRA et al. (2017) & Antimicrobial and antimalarial activities. \\
\hline \multirow[t]{3}{*}{ Chemical studies } & TELES et al. (2006) & Aromatic compounds and biological activities against carcinoma in rats. ${ }^{*}$ \\
\hline & TELES et al. (2005) & Structural analysis of compounds; antifungal and biological activities. ${ }^{*}$ \\
\hline & CHAPLA et al. (2014) & Isolation and identification of natural products. \\
\hline Other subjects & FERNANDES et al. (2018) & Multitrophic interaction between bees, plants, and endophytes. \\
\hline
\end{tabular}

* Biological assays were performed on the crude extracts produced by the studied endophytic fungi.

A chemical study on the extract of Mycospharella sp., an endophytic fungus associated with the endemic plant of the Cerrado Eugenia bimarginata, was performed by De Oliveira et al. (2018). The authors isolated two new usnic acid derivatives: mycousfuranine (1) and mycousnicdiol (2) (Figure 3). The two new compounds were isolated from the ethyl acetate fraction of the extract using chromatographic techniques. Compounds 1 and 2 exhibited moderate antifungal activity against Cryptococcus neoformans and Cryptococcus gattii.

Silva et al. (2006) isolated new cadinan sesquiterpene derivatives from the crude extract of Phomopsis cassiae, an endophytic fungus isolated from Cassia spectabilis, a plant species found in the Cerrado. The fungus was cultivated in a liquid medium and extracted with ethyl acetate. Bioassay-guided fractionation was used to isolate the compounds 3,9,12-trihydroxycalamenenes (3 and 4), 3,12-dihydroxycalamenene (5), 3,12-dihydroxycadalene (6), and 3,11,12-trihydroxycadalene (7) (Figure 3). Compounds 4 and 7 showed antifungal activity when evaluated against Cladosporium sphaerospermum and C. cladosporioides.

A similar study was conducted by Chapla et al. (2014), which evaluated the secondary metabolites produced by Phomopsis sp., an endophyte associated with the Senna spectabilis plant. A novel natural product, 2-hydroxy-alternariol (8), together with known compounds, cytochalasins $\mathrm{J}$ and $\mathrm{H}, 5$ '-epialtenuene, and the mycotoxins, alternariol monomethyl ether (AME), alternariol ( $\mathrm{AOH})$, and cytosporone $\mathrm{C}$, were obtained using chromatographic techniques. Cytochalasin $\mathrm{H}$ inhibits acetylcholinesterase (AChE) enzyme in vitro and exhibits antifungal activity. In addition, cytochalasins $\mathrm{J}$ and $\mathrm{H}$, and alternariol showed potent inhibitory effects on reactive oxygen species (ROS) produced by human neutrophils and may be promising targets for the development of anti-inflammatory agents.

Studying the metabolites produced by Periconia atropurpurea, a fungus isolated as an endophyte from the Xylopia aromatica plant, Teles et al. (2006) isolated several new aromatic compounds exhibiting biological activity. 6,8-Dimethoxy-3-(2'-oxo-propyl)-coumarin (9) and 2,4-dihydroxy-6-[(1'E,3'E)-penta-1',3'-dienyl]-benzaldehyde (10), in addition to the known compound, periconicin B (11), were isolated from the ethyl acetate fraction of the extract. Biological analyzes showed that compound 10 exhibits strong antifungal activity against
C. sphaerospermum and C. cladosporioides, and compound 11 showed potent cytotoxic activity against the two cell lines studied (human cervical carcinoma (HeLa) and Chinese hamster ovary (CHO) cells).

In another chemical study, Teles et al. (2005) isolated a new benzopyran from the extract of Curvularia sp. The fungus was isolated as an endophyte of the leaves of Ocotea corymbosa, a native plant found in the Brazilian Cerrado. Chromatographic analysis led to the isolation of two new benzopyran derivatives, (2'S)-2-(propan-2'-ol)-5-hydroxybenzopyran-4-one (12) and 2,3-dihydro-2-methyl benzopyran-4,5-diol (13), and two known benzopyrans, 2-methyl-5-methoxy-benzopyran4-one (14) and (2R)-2,3-dihydro-2-methyl-5-methoxy-benzopyran-4one (15). Compounds 12 and 14 showed antifungal activity against C. sphaerospermum and C. Cladosporium. In addition, compound 12
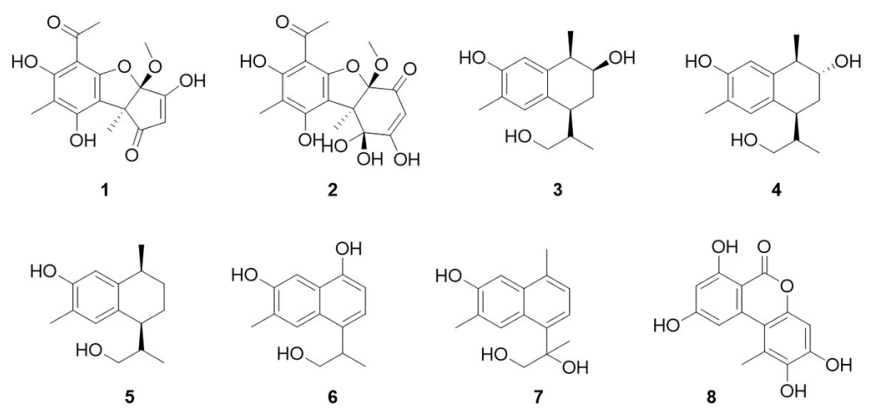

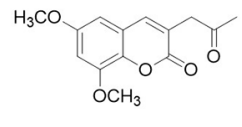

9

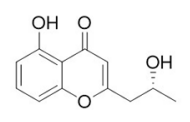

12

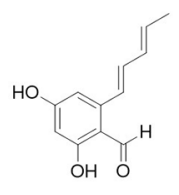

10

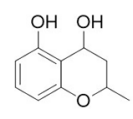

13

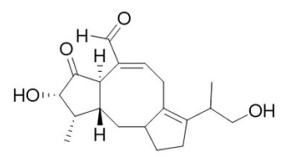

11

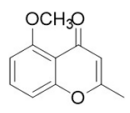

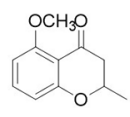

Figure 3. Chemical structures of the compounds isolated from endophytic fungi 
was able to induce cell proliferation $(70 \%$ in $\mathrm{HeLa}$ cells and $25 \%$ in CHO cells).

In all the studies on the chemical diversity of endophytic fungi, new compounds or new natural products exhibiting a range of bioactivities were isolated, which shows the great potential of endophytes in the production of new and bioactive secondary metabolites, as well as the unexplored chemical diversity of endophytes isolated from the Cerrado.

\section{Other Cerrado endophyte fungal studies}

In addition to the huge potential for the discovery of new pharmaceutical substances from this wide variety of plant species and secondary metabolites (Gonçalves et al. 2017), endophytic fungi are also considered for application in other areas, such as the production of enzymes, flavors and flavors of value in the food/cosmetics industry, and hydrocarbons and fatty acids for use in energy production (Corrêa et al. 2014, Souza et al. 2004). Owing to this biotechnological potential, these microorganisms have been the target of various chemical and biological studies.

Lisboa et al. (2013) evaluated a new method for the detection of esterase producing microorganisms via the in vitro detection of enzymatic activity using a $\mathrm{pH}$ indicator (bromothymol blue). This method evaluated the production of esterases using endophytic fungi isolated from Cerrado and Atlantic Forest plants. The results showed that the method was efficient, fast, and cheap with low reagent consumption and easy development. The authors also highlighted the potential of endophytic fungi isolated from Cerrado and Atlantic Forest plant species as successful producers of esterases.

In order to detect monooxygenase and alcohol dehydrogenase activity, Pinedo-Rivilla et al. (2009) studied the biotransformation of pro-chiral ketones (4-ethylcyclohexanone and acetophenone) by filamentous fungi and endophytic fungi isolated from Casearia sylvestris. The analyses showed the biocatalytic potential for obtaining biotransformation compounds with high enantiomeric purity. The main reaction pathways involved reduction and hydroxylation in various positions. In addition, trans-4-ethyl-1-(1S-hydroxyethyl)cyclohexanol was reported for the first time, which was obtained via an atypical acyl reaction and indicated the biocatalytic potential of the endophytic fungus Eutypa lata.

Vitorino \& Silva (2013) evaluated the metabolic response of microplants in vitro to inoculation with endophytic bacteria and fungi isolated from Hypti smarrubioides Epling. The results of the study indicated that the endophyte-plant interaction led to qualitative and quantitative changes in the host phytochemical profile because some of the compounds evaluated in the host plant were produced only after inoculation with the endophytes. According to the authors, this technique may be an important strategy for the production of bioactive compounds from medicinal plants.

Studying the interactions between microorganisms and plant species also has a significant biotechnological relevance because in addition to contributing to understanding the chemical and ecological processes, it can result in the discovery of new bioactive substances (Dos Santos \& Varavallo 2011).

Fernandes et al. (2018) studied the multitrophic interaction between endophytic fungi, bees, and Baccharia dracunculifolia plant, a plant species found in the Cerrado, to evaluate whether there was any relationship between the resin collected by bees and fungal endophytes, considering the sex of the host plant. The nine identified taxa were found exclusively in damaged leaves. The endophyte richness and proportion of leaf shoot damage did not change between the plant sexes, however, the composition of endophytes changed with gender. These results reinforced the importance of physical damage to plant tissues as a gateway to endophyte infection, as well as the selective potential of chemical differences in the host plant sex against invasion by microorganisms.

\section{Conclusions}

This survey conducted a systematic review of the literature and resulted in 418 articles using selected keywords and platforms. After critical analysis, 14 articles on endophytic fungi isolated from the Cerrado were selected. The analysis of these articles showed the potential of Cerrado plants to act as a rich and diversified repository of endophytic fungi, which have proven to be a potential source of novel and bioactive substances, and have applications in several areas of interest.

The endophytic production of secondary metabolites varies according to the biology and growth conditions of the microorganism and are produced as an adaptation to specific functions in nature. They play vital roles in vivo owing to the numerous metabolic interactions observed between endophytes and their hosts, such as signaling, defense, and regulation of symbiosis (De Andrade et al. 2018). In view of this, the search for new bioactive molecules should focus on organisms that inhabit new ecosystems or niches that are still unexplored, because natural products are adapted to a specific function in nature (Azevedo et al. 2000, Nisa et al. 2015).

Although the Cerrado is considered as one of the largest areas of biodiversity in the world containing $\sim 7,000$ plant species, there are few studies on endophytic fungi associated with these species. Consequently, the development of chemical and biological studies on the microbiota associated with Brazilian Cerrado plant species, particularly in the central, northern, and northeastern regions of Brazil are recommended, given that most of these studies are related to plant species. The Southeast and Midwest regions contain rich and valuable biodiversity that are yet to be explored.

\section{Acknowledgments}

This work was funded by "Produtividade em Pesquisa" program from Universidade Federal do Tocantins (UFT) (Propesq/UFT). SBSD acknowledges the Aperfeiçoamento de Pessoal de Nível Superior (Capes) for scholarship.

\section{Author Contributions}

Sara Bruna Souza Dantas: substantial contribution in the concept and design of the study, to data collection and to data analysis and interpretation; wrote, added intellectual content and review the final version of the manuscript; provided significant contribution to manuscript preparation.

FlaviaAlessandra Mota Alves: substantial contribution in the concept and design of the study, to data collection and to data analysis and interpretation; wrote, added intellectual content and review the final version of the manuscript; provided significant contribution to manuscript preparation.

Vanessa Mara Chapla: substantial contribution in the concept and design of the study, data analysis and interpretation; added intellectual 
content and review the final version of the manuscript; provided significant contribution to manuscript preparation.

\section{Conflicts of Interest}

The authors declare that they have no conflict of interest related to the publication of this manuscript.

\section{References}

ALY, A.H, DEBBAD, A., PROKSCH, P. 2011. Fungal endophytes: unique plant inhabitants with great promises. Appl. Microbiol. Biotechnol. 90: 1829-1845.

ARNOLD, A.E. \& HERRE, E.A. 2003. Canopy cover and leaf age affect colonization by tropical fungal endophytes: Ecological pattern and process in Theobroma cacao (Malvaceae). Mycologia 95: 388-398.

ARNOLD, A.E., MEJIA, L.C., KYLLO, D., ROJAS, E.I., MAYNARD, Z., ROBBINS, N., HERRE, E.A. 2003. Fungal endophytes limit pathogen damage in a tropical tree. Proc. Natl. Acad. Sci. 100: 15649-15654.

ARNOLD, A.E. 2007. Understanding the diversity of foliar endophytic fungi: progress, challenges, and frontiers. Fungal Biol.Rev. 21(2-3): 51-66.

AZEVEDO, J.L., MACCHERONI, W., PEREIRA, J.O., ARAUJO, W.L. 2000. Endophytic microorganisms: a review on insect control and recent advances on tropical plants. Electron. J. Biotechn. 3(1): 15-16.

AZEVEDO, J.L. 1998. Microrganismos Endofíticos. In Ecologia Microbiana. Ed. EMBRAPA, Jaguariúna-SP, p.117-137.

CARROLL, G.C. 1988. Fungal endophytes in stems and leaves: From latent pathogen to mutualistic symbiont. Ecology 69(1): 2-9.

CARVALHO, C.R., GONÇALVES, V.N., PERREIRA, C.B., JOHANN, S., GALLIZA, I.V., ALVES, T.M., ROSA, L.H. 2012. The diversity, antimicrobial and anticancer activity of endophytic fungi associated with the medicinal plant Stryphnodendron adstringens (Mart.) Coville (Fabaceae) from the Brazilian savannah. Symbiosis 57(2): 95-107.

CHAPLA, V., ZERAIK, M., XIMENES,V., ZANARDI, L., LOPES, M., CAVALHEIRO, A., ARAUJO, A. 2014. Bioactive secondary metabolites from Phomopsis sp., an endophytic fungus from Senna spectabilis. Molecules 19(5): 6597-6608.

COLLADO, J., PLATAS, G., GONZALEZ, I., PELAEZ, F. 1999. Geographical and seasonal influences on the distribution of fungal endophytes in Quercus ilex. New Phytologist. 144(3): 525-532.

CORREA, R.C.G., RHODEN, A.S., MOTA, T.R., AZEVEDO, J.L., PAMPHILE, J.A.Á., SOUZA, C.G.M. 2014. Endophytic fungi: expanding the arsenal of industrial enzyme producers. Journal of Industrial Microbiology \& Biotechnology 41(10): 1467-78.

DE ANDRADE, H.F., ARAUJO, L.C.A., SANTOS, B.S., PAIVA, P.M.G., NAPOLEÃO, T.H., CORREIA M.T.S., OLIVEIRA, M.B.M., LIMA, G.M.S., XIMENES, R.M., SILVA, T.D., SILVA, G.R., SILVA M.V. 2018. Screening of endophytic fungi stored in a culture collection for taxol production. Braz. J. Microbiol. 49 (suppl 1): 59-63.

DE OLIVEIRA, D.M., PEREIRA, C.B., MENDES, G., JUNKER, J., KOLLOFF, M., ROSA, L.H., COTA, B.B. 2018. Two new usnic acid derivatives from the endophytic fungus Mycosphaerella sp. Z. Naturforsch C. J. Biosci. 73(11-12): 449-455.

ESPOSITO, E. \& AZEVEDO, J.L. 2010. Fungos: uma introdução á biologia, bioquímica e biotecnologia. 2nd ed. Educs, Caxias do sul, p. 535-556.

FAETH, S.H. \& HAMMON, K.E. 1997. Fungal endophytes in oak trees: Longterm patterns of abundance and associations with leaf miners. Ecology 78(3): 810-819.

FERNANDES, G.W., OKI, Y., BELMIRO, M.S., RESENDE, F.M., JUNIOR, A.C., DE AZEVEDO, J.L. 2018. Multitrophic interactions among fungal endophytes, bees, and Baccharis dracunculifolia: resin tapering for propolis production leads to endophyte infection. Arthropod-PlantInteractions 12(3) 329-337.

FERRACINI, V.L. 1995. Óleos essenciais de Baccharis e sua interação com insetos polinizadores. Campinas, UNICAMP, Tese de doutorado, p. 205.
FERREIRA, M.C., CANTRELL, C.L., WEDGE, D.E., GONÇALVES, V.N., JACOB, M.R., KHAN, S., ROSA, L.H. 2017. Diversity of the endophytic fungi associated with the ancient and narrowly endemic neotropical plant Vellozia gigantea from the end angered Brazilian rupestrian grasslands. Biochem. Syst. Ecol. 71: 163-169.

FERREIRA, M.C., CANTRELL, C.L., WEDGE, D.E., GONÇALVES, V.N., JACOB, M.R., KHAN, S., ROSA, L.H. 2017. Antimycobacterial and antimalarial activities of endophytic fungi associated with the ancient and narrowly endemic neotropical plant Vellozia gigantea from Brazil. Memórias do Instituto Oswaldo Cruz 112(10):692-697.

GONÇALVES, B., BASTOS, E., HANNA, S. 2017. Prospecção tecnológica de fungos endófitos e aplicações na indústria farmacêutica. Cadernos de Prospecção 10(1): 56-67.

HUANG, Y., WANG, J., LI, G., ZHENG, Z., SU, W. 2001. Antitumor and antifungal activities in endophytic fungi isolated from pharmaceutical plants Taxus mairei, Cephalataxus fortunei and Torreya grandis. FEMS Immunol. Med. Microbiol. 31(2): 163-167.

ICMBio- Instituto Chico Mendes de Conservação da Biodiversidade. 2019. Biodiversidade-Cerrado Disponível em: http://www.icmbio.gov.br/cbc/ conservacao-da-biodiversidade/biodiversidade.html. (último acesso em 07/10/2019)

LACAVA, P.T., SEBASTIANES, F.L.S., AZEVEDO, J.L. 2004. Fungos endofíticos: biodiversidade e aplicações biotecnológicas. In Fungos: uma introdução à biologia, bioquímica e biotecnologia. Educs, Caxias do Sul, cp. 8 .

LISBOA, H.C.F., BIASETTO, C.R., MEDEIROS, J.B.D., ARAUJO, A.R., SILVA, D.H.S., TELES, H.L., TREVISAN, H.C. 2013. Endophytic fungi producing of esterases: evaluation in vitro of the enzymatic activity using pH indicator. Braz. J. Microbio. 44(3): 923-926.

NISA,H., KAMILI, A.N., NAWCHOO, I.A., SHAFI, S., SHAMEEM, N., BANDH, S.A. 2015. Fungal endophytes as prolific source of phytochemicals and other bioactive natural products: a review. Microb. Pathog. 82: 50-59.

NORILER, A.S., SAVI, D.C., ALUIZIO, R., PALACIO-CORTEZ, A.M., POSSIEDE, Y.M., GLIENKE, C. 2018. Bioprospecting and structure of fungal endophyte communities found in the Brazilian biomes, Pantanal and Cerrado. Front. Microbiol. 9: 1526-1532.

OLIVEIRA, L.G.D., PUPO, M.T., VIEIRA, P.C. 2013. Explorando produtos naturais microbianos nas fronteiras da química e da biologia. Quím. Nova 36(10): 1577-1586.

PINEDO-RIVILLA, C., CAFEU, M.C., CASATEJADA, J.Á., ARAUJO, Â.R., COLLADO, I.G. 2009. Asymmetric microbial reduction of ketones: absolute configuration of trans-4-ethyl-1-(1S-hydroxyethyl) cyclohexanol. Tetrahedron: Asymmetry 20(23): 2666-2672.

RODRIGUES, K.F. 1994. The foliar fungal endophytes of the Amazonian palm Euterpe oleracea. Mycologia 86(3): 376-385.

RODRIGUES, T., BELMOK, A., CATÃO, E., KYAW, C.M. 2016. Archaea in natural and impacted Brazilian environments. Archaea. 1-14

SAVI, D.C., ALUIZIO, R., GLIENKE C. 2019. Brazilian plants: an unexplored source of endophytes as producers of active metabolites. Planta med. 85(08): 619-636.

SILVA, G.H., TELES, H.L., ZANARDI, L.M., YOUNG, M.C.M., EBERLIN, M.N., HADAD, R., ARAUJO, Â.R. 2006. Cadinane sesquiterpenoids of Phomopsis cassiae, an endophytic fungus associated with Cassia spectabilis (Leguminosae). Phytochem. 67(17): 1964-1969.

SILVA, A.F., RABELO, M.F.R., ENOQUE, M.M. 2015. Diversidade de angiospermas e espécies medicinais de uma área de Cerrado. Rev. Bras. Pl. Med. 17(4): 1016-1030.

SOUZA, A.Q.L.D., SOUZA, A.D.L.D., ASTOLFI FILHO, S., PINHEIRO, M.L.B., SARQUIS, M.I.D.M., PEREIRA, J.O. 2004. Antimicrobial activity of endophytic fungi isolated from Amazonian toxic plants: Palicourea longiflora (aubl.) rich and Strychnoscogens bentham. Acta amazônica 34(2):185-195.

TELES, H.L., SILVA, G.H., CASTRO-GAMBOA, I., BOLZANI, V.S., PEREIRA, J.O., COSTA-NETO, C.M., ARAUJO, Â.R. 2005. .Benzopyrans from Curvularia sp., an endophytic fungus associated with Ocotea corymbosa (Lauraceae). Phytochem. 66(19): 2363-2367. 
Dantas, S.B.S. et al.

TELES, H.L., SORDI, R., SILVA, G.H., CASTRO-GAMBOA, I., BOLZANI, V.S., PFENNING, L.H., ARAUJO, Â.R. 2006. Aromatic compounds produced by Periconia atropurpurea, an endophytic fungus associated with Xylopia aromatica. Phytochem. 67(24):2686-2690.

VERDI, L.G., BRIGHENTE, M.C., PIZZOLATTI, M.G. 2005. Gênero Baccharis (Asteraceae): aspectos químicos, econômicos biológicos. Quím. Nova 28(1): 85-94.

VIEIRA, M.L., JOHANN, S., HUGHES, F.M., ROSA, C.A., ROSA, L.H. 2014. The diversity and antimicrobial activity of endophytic fungi associated with medicinal plant Baccharis trimera (Asteraceae) from the Brazilian savannah. Can. J. Microbiol. 60(12): 847-856.
VITORIANO, L.C., SILVA, F.G., LIMA, W.C., SOARES, M.A., PEDROSO, R.C.N., SILVA, M.R., JANUÁRIO, A.H. 2013. Metabolic response induced by endophytic fungi and bacteria in $H$. marrubioides Epling in vitro microplants. Quím. Nova 36(7):1014-1020.

WWF. Mapa - Bioma Cerrado. 2019. Disponível em:www.wwf.org.br/ natureza_brasileira/questoes_ambientais/biomas/bioma_cerrado/mapa bioma_cerrado. (último acesso em 20/11/2019)

Received: 02/07/2020

Revised: 14/09/2020

Accepted: 11/02/2021

Published online: 31/03/2021 